\title{
Pengembangan Teknik Jahit Celup (Tritik) dengan Pola Geometris
}

\author{
Bintan Titisari ${ }^{1}$, Kahfiati Kahdar $^{1} \&$ Intan Rizky Mutiaz ${ }^{2}$ \\ ${ }^{1}$ Kelompok Keahlian Kriya Tekstil, Fakultas Seni Rupa dan Desain, \\ Institut Teknologi Bandung, Jalan Ganesa No. 10 Bandung 40132, Indonesia \\ ${ }^{2}$ Kelompok Keahlian Desain Komunikasi Visual, Fakultas Seni Rupa dan Desain, \\ Institut Teknologi Bandung, Jalan Ganesa No. 10 Bandung 40132, Indonesia \\ Email: bintan.titisari@gmail.com
}

\begin{abstract}
Abstrak. Teknik jahit celup biasa dikenal dengan istilah tritik, yang berarti titik, merupakan teknik tekstil kelompok celup rintang. Tritik adalah cara menghias kain putih dengan menjahit jelujur lalu ditarik kemudian dicelup dan motif terbentuk setelah benang dilepaskan. Teknik tritik digunakan untuk membuat kain sasirangan, kain tradisional Kalimantan Selatan, Indonesia. Proses menjahit pada tritik dikerjakan secara tradisional tanpa ketentuan yang jelas, sehingga pengembangan desain motif belum maksimal. Melihat kondisi tersebut, penelitian ini menggunakan pola geometris pada teknik tritik untuk melihat kemungkinan dihasilkan motif berbeda. Dengan metode eksperimen kualitatif didapat ketentuan mengenai aturan jahitan yang diaplikasikan pada pembuatan pola geometris. Penggunaan pola geometris menghasilkan motif lebih teratur dengan tetap terkesan samar sebagai ciri khas tritik. Pewarnaan bertahap dan pengaturan jarak menghasilkan efek ilusi optik (kedalaman, arah, dan gerak). Motif tersebut diaplikasikan pada produk fashion dengan menonjolkan efek ilusi optik untuk menghasilkan siluet pada pakaian wanita.
\end{abstract}

Kata kunci: geometri; jahit celup rintang; pola; sasirangan; tritik.

\begin{abstract}
Resist stitch-dyeing, also known locally as tritik (lit. dots), is resist dye textile weaving technique. Tritik is a method to embellish white cloth by tacking, which is then dyed and removed. The motif is formed after the thread is removed. Tritik methods and techniques are less popular compared to batik or dyed ikat. It is, however, used in making sasirangan cloth, a traditional cloth from South Kalimantan, Indonesia. The stitching has always been done traditionally due to the lack of clear convention on stitching as a resist-media. Thus, development of motif designs is not in full capacity. Taking into consideration the above, this study is carried out to create new geometric patterns using tritik techniques. Qualitative experiment methods are used to obtain ideal stitching parameters, which could later be applied in creating geometric patterns. The use of geometric patterns creates more organized motifs but still showing blurry impression, a distinctive feature of tritik. The combination of gradual colouring and evenly-spaced tacking creates optical illusions on motifs (depth, direction, and motion). The motifs may be applied to fashion products by accentuating optical illusions to create silhouettes on women's clothing.
\end{abstract}

Keywords: geometric; pattern; resist stitch dyeing; sasirangan; tritik.

Received Oktober $2^{\text {nd }}, 2012$, Revised September $27^{\text {th }}, 2013$, Accepted for publication January $16^{\text {th }}, 2014$. Copyright () 2014 Published by LPPM ITB, ISSN: 1978-3078, DOI: 10.5614/itbj.vad.2014.6.2.4 


\section{Pendahuluan}

Kain-kain tradisional Indonesia saat ini telah dikenal secara meluas oleh tidak hanya masyarakat Indonesia tetapi juga dunia. Setiap daerah di Indonesia mempunyai kain tradisional yang mencirikan keunikan budaya daerah tersebut dengan teknik pembuatan kain yang berbeda pada setiap daerahnya. Teknik jahit celup atau tritik merupakan salah satu teknik tekstil yang digunakan untuk membuat motif pada beberapa kain tradisional Indonesia, yaitu kain tritik dari Jawa Tengah, kain plangi dari Sumatera Selatan, dan kain sasirangan dari Kalimantan Selatan. Kain sasirangan dipilih menjadi objek penelitian melihat perkembangan desain motif pada kain sasirangan yang sudah dilakukan dan masih mempunyai potensi yang besar untuk dikembangkan.

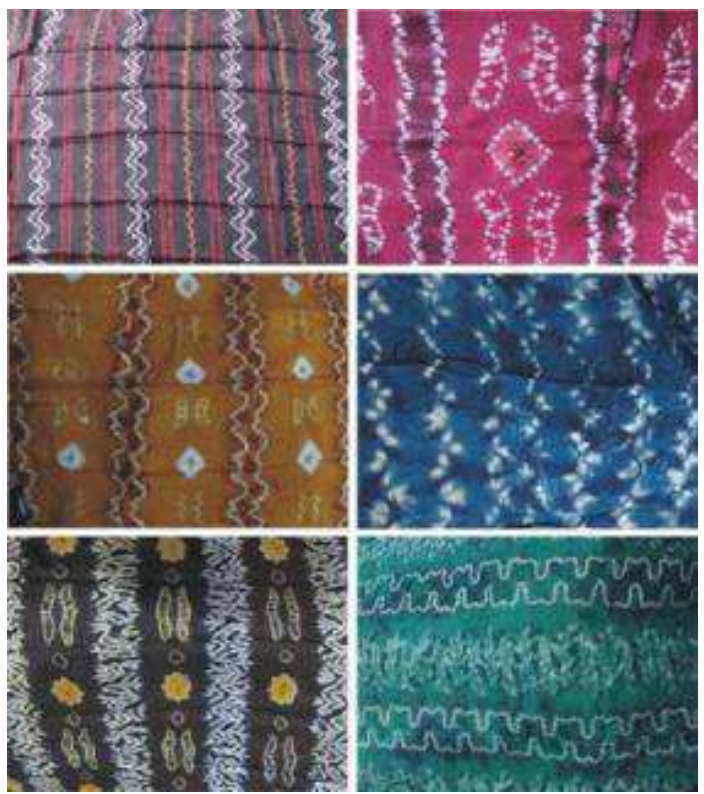

Gambar 1 Motif-motif kain sasirangan menggunakan teknik tritik.

Kain sasirangan merupakan kain tradisional yang pada awalnya tidak digunakan secara bebas karena dianggap sebagai obat untuk menyembuhkan berbagai macam penyakit. Ciri khas motif kain sasirangan yang selama ini dibuat adalah kombinasi dari motif garis tidak beraturan berjumlah dua atau tiga garis dan motif figuratif yang dikomposisikan secara vertikal [1]. Di samping corak dan warna tradisional yang sudah baku, saat ini terlihat pula corak yang baku dengan permainan nuansa yang lebih beragam, mengikuti selera yang berlaku pada saat ini (Gambar 1) [2]. Pengembangan juga dilakukan dengan membuat ragam hias baru pada motif kain sasirangan. 
Motif dibuat dengan cara menghias kain putih di mana pola hiasan dijelujur dengan benang lalu ditarik erat-erat sebelum dicelup, setelah kering benang dilepaskan dan timbullah motif-motif putih atas dasar bewarna [3]. Pada teknis pengerjaannya, teknik tritik melalui 4 proses yaitu proses penggambaran pola di atas kain, proses penjahitan jelujur, proses penarikan/pengerutan, dan proses pewarnaan/pencelupan (Gambar 2). Proses penggambaran pola dan proses penjahitan jelujur merupakan proses yang menentukan seberapa besar area perintang yang nantinya akan menghasilkan motif. Area perintang terbentuk dari kerutan yang disebabkan karena adanya jahitan yang ditarik lalu diikat, dimana besar dan bentuk kerutan tersebut ditentukan oleh jarak dan pola jahitan. Hingga kini, pembuatan pola pada teknik tritik (khususnya di kain sasirangan) belum memperhatikan ketentuan pada jarak dan pola jahitan sehingga berpengaruh terhadap motif yang dihasilkan.
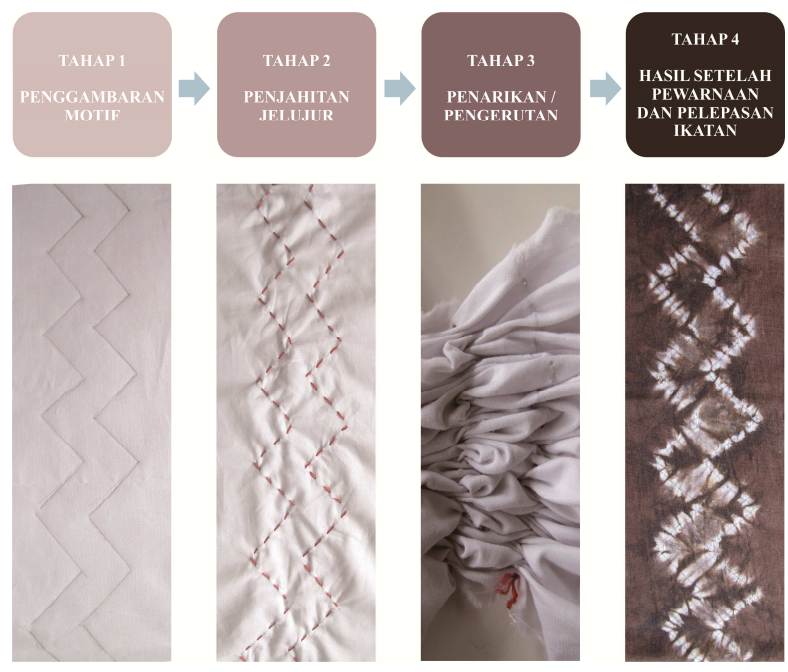

Gambar 2 Proses teknik jahit celup secara umum (adaptasi dari Baldinger [4]).

Melihat potensi yang dapat dikembangkan serta adanya permintaan dari pasar dunia, maka pengembangan teknik tritik dilakukan untuk memberikan sudut pandang yang berbeda pada proses pengerjaan teknik tersebut. Teknik tritik merupakan teknik celup rintang yang kedayagunaannya tinggi dalam menghasilkan motif karena teknik ini mempunyai kontrol terhadap motif yang ingin dihasilkan [5]. Penggunaan pola geometris pada teknik tritik berpotensi untuk dapat menghasilkan motif berbeda dengan motif yang selama ini cenderung lebih tidak teratur. Bentuk geometris merupakan bidang yang terukur secara sudut sehingga dapat membuat bentuk yang kongruen dan apabila 
diulang dapat menghasilkan pola [6]. Pola geometris diterapkan pada penempatan ukuran, jarak, dan posisi jahitan.

Pengembangan pola dilakukan tidak hanya secara bentuk namun juga pada metode pembuatan pola yang selama ini masih tradisional. Pola geometris dibuat menggunakan program aplikasi komputer yaitu program vector graphics editor (Adobe Illustrator) merupakan salah satu bagian dari CAD (Computer Aided Design) yang diharapkan dapat menghasilkan pola presisi dalam bentuk vektor serta pengembangan desain pola teknik jahit celup dapat dilakukan lebih maksimal [7]. Penggunaan program aplikasi komputer disesuaikan pada kondisi perkembangan digital textiles saat ini yang telah berkembang dengan pesat dan kedepannya diharapkan dapat dikonversi dengan program aplikasi lanjutan salah satunya CAM (Computer Aided Manufacturer) sehingga menghasilkan motif lebih presisi dan terencana dalam jumlah banyak [8]. Motif yang dihasilkan dari pola geometris lalu diimplementasikan pada produk fashion pada tahap perancangan, dengan maksud memberikan nilai lebih dari produk fashion.

\section{$2 \quad$ Metodologi}

Metodologi penelitian ini menggunakan pendekatan kualitatif dan eksperimen. Metode kualitatif digunakan untuk mendapatkan data primer dan sekunder mengenai teknik tritik dan penggunaannya pada kain sasirangan. Pada metode eksperimen akan dilakukan dalam dua tahap, yaitu:

1. Tahap eksperimen pertama, mengidentifikasi hubungan ukuran, jarak, serta posisi jahitan terhadap motif yang dihasilkan.

2. Tahap eksperimen kedua, penerapan pola geometris yang terukur pada teknik tritik menggunakan hasil analisa dari eksperimen pertama.

Tahap eksperimen pertama merupakan implementasi dari pengembangan teknik jahit pada teknik tritik dalam hal ukuran, jarak dan posisi jahitan, namun teknik jahit tetap mengunakan teknik jahit jelujur yang sudah dikuasai oleh pengrajinpengrajin kain sasirangan.

\subsection{Material Tekstil dan Zat Pewarna}

Dalam proses eksperimen, material tekstil yang digunakan ada tiga macam, yaitu kain sutra, katun, dan kanvas. Ketiga material tekstil tersebut dipilih berdasarkan survey penggunaan material kain pada daerah yang menggunakan teknik tritik. Mayoritas pengrajin menggunakan material katun dan sutra sebagai material utama, dan rayon serta polyester sebagai material tambahan, maka katun dan sutra dipilih karena merupakan material tekstil berbahan serat 
alam. Kain kanvas dipilih sebagai material uji karena kesamaan serat dengan kain katun, yaitu kapas, namun kain kanvas memiliki diameter tetal benang yang lebih besar dibandingkan dengan kain katun sehingga mempunyai karakteristik berbeda dari kain katun. Diharapkan kain kanvas nantinya dapat menjadi salah satu alternatif material dalam menggunakan teknik jahit celup dimana peruntukkannya dapat lebih luas, tidak hanya untuk produk fashion. Spesifikasi material yang digunakan pada eksperimen adalah sebagai berikut:

Tabel 1 Spesifikasi material kain untuk eskperimen.

\begin{tabular}{|c|c|c|c|c|}
\hline Spesifikasi & Sutra & Katun & Kanvas & Ket Lain \\
\hline Berat kain $\mathrm{g} / \mathrm{m}^{2}$ & 68,8 & 92,9 & 244,6 & \multirow{8}{*}{$\begin{array}{c}\text { Tex }\left(\mathrm{Ne}_{1}\right) \\
\text { untuk serat } \\
\text { selulosa, } \\
\text { Tex }(\mathrm{Td}) \\
\text { untuk serat } \\
\text { protein }\end{array}$} \\
\hline Kontruksi : & & & & \\
\hline $\begin{array}{l}\text { Jumlah Tetal lusi } \\
\text { (hl/inci) }\end{array}$ & $115,0(292)$ & 44,0 (112) & $27,7(70)$ & \\
\hline $\begin{array}{l}\text { Jumlah Tetal pakan } \\
\text { (hl/inci) }\end{array}$ & $54,0(137)$ & $35,0(89)$ & $14,4(37)$ & \\
\hline $\begin{array}{l}\text { No Benang Lusi Tex } \\
\left(\mathrm{Ne}_{1} / \mathrm{Td}\right)\end{array}$ & $3,5(31,5)$ & $10,7(55,2)$ & $51,4(11,5)$ & \\
\hline $\begin{array}{l}\text { No Benang Pakan Tex } \\
\left(\mathrm{Ne}_{1} / \mathrm{Td}\right)\end{array}$ & $3,9(35,1)$ & $10,9(54,2)$ & $51,1(11,6)$ & \\
\hline Jenis Anyaman & $\begin{array}{c}\text { Satin } \\
\text { lusi } 5 \text { gun }\end{array}$ & Polos & Polos & \\
\hline Kelangsaian & 0,31 & 0,62 & 0,70 & \\
\hline
\end{tabular}

(Sumber : Hasil uji tes kain di Balai Besar Tekstil, 11 Juli 2012)

Berdasarkan Tabel 1, bahan tekstil yang digunakan dalam eksperimen adalah bahan tekstil berbahan dasar alami yaitu katun dan sutra, maka zat pewarna yang tepat untuk bahan tekstil katun adalah direct dyes dan acid dyes [9]. Saat ini sudah terdapat jenis zat perwarna baru yaitu all purposed dyes, merupakan campuran dari direct dyes dan acid dyes yang diperuntukkan untuk semua jenis bahan tekstil. Maka untuk memudahkan proses pewarnaan, zat pewarna yang digunakan dalam proses pewarnaan adalah jenis zat pewarna direct dyes dan all purposed dyes.

\subsection{Prosedur Pengerjaan Eksperimen}

Prosedur pengerjaan eksperimen diterapkan pada kedua tahap eksperimen, yaitu sebagai berikut:

1. Pola-pola digambarkan menggunakan program aplikasi komputer yaitu program vector graphics editor (Adobe Illustrator) dengan skala perbandingan 1:1 agar ukuran dan jarak dapat terukur dengan tepat, lalu pola tersebut dicetak pada kertas. 
2. Pola yang sudah tercetak pada kertas dipindahkan ke kain melalui karbon khusus kain dengan teknik jiplak atau menggunakan meja tracing.

3. Pola yang terdapat pada kain lalu dijahit menggunakan benang katun tebal. Kain yang telah dijahit, ditarik lalu diikat dengan erat.

4. Kain yang sudah ditarik (kondisi sudah berkerut sesuai pola) direndam pada air jernih untuk mempermudah proses pewarnaan lalu dimasukkan pada larutan pewarna.

5. Pewarna yang digunakan untuk eksperimen ini adalah zat warna direct dan all-purposed dyes dengan perbandingan sebagai berikut :

a. Zat warna dicampur dengan garam dan soda ass sebagai mordan, perbandingan zat warna : garam : sodaass $=50$ gram $: 50$ gram $: 50$ gram

b. Lalu zat warna dimasukkan ke dalam air yang telah mendidih, perbandingan zat warna : air $=50$ gram $: 3$ liter.

c. Perbandingan kain dan larutan warna $=30$ gram : 3 liter (berat kain dihitung dalam keadaan kering).

6. Proses pencelupan warna dilakukan selama 15 menit.

7. Setelah dingin, jahitan dibuka dan kain dibilas pada air mengalir lalu dikeringkan menggunakan sinar matahari.

\subsection{Tahap Eksperimen Pertama}

Faktor-faktor yang menjadi penentu motif dalam teknik tritik adalah teknik jahit, pola, material tekstil, dan warna. Tahap eksperimen yang pertama ini difokuskan pada pengembangan teknik jahit dengan mengetahui hubungan jarak, ukuran, serta posisi jahitan terhadap motif yang dihasilkan. Teknik jahit yang digunakan pada teknik tritik adalah teknik jahit jelujur (running stitch). Teknik jelujur merupakan teknik jahit paling sederhana yang menghasilkan garis putus-putus. Variasi dapat dilakukan pada ukuran, jarak dan posisi jahitan (Gambar 3) [10]. Pada teknik tritik, variasi teknik jahit jelujur akan mempengaruhi area perintang yang terbentuk dari kerutan disebabkan karena adanya penarikan jahitan lalu diikat.

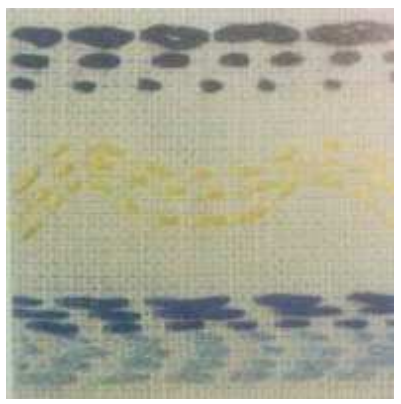

Gambar 3 Teknik jahit jelujur dan variasi pada jarak jahitan [10]. 
Pada eksperimen pertama. jahitan akan disusun menjadi barisan diletakkan dengan kisi-kisi di antaranya triangular, square, diamond yang nantinya dijadikan sebagai pola posisi jahitan. Faktor jahitan, pola dan material tekstil akan menjadi variabel bebas pada eksperimen ini, sedangkan faktor warna sebagai variabel tetap. Warna biru dipilih pada proses eksperimen karena warna biru mempunyai intensitas rendah sehingga akan menimbulkan kontras dengan warna dasar kain berwarna putih, untuk mempermudah proses analisa motif. Eksperimen dilakukan dalam lima tahap untuk mendapatkan hubungan antara ukuran, jarak, dan posisi jahitan pada teknik jahit celup. Eksperimen difokuskan pada tiga variabel yaitu ukuran, jarak, dan posisi jahitan pada tiga material tekstil yang mempunyai perbedaan karakteristik.Ukuran jahitan yang digunakan dalam eksperimen ini adalah milimeter dengan jangkauan ukuran dimulai dari 5-20 milimeter dengan perbedaan jarak 5 milimeter. Jumlah garis yang diterapkan pada eksperimen ini adalah 1-3 garis, dengan dasar dua garis mewakili pengulangan genap dan tiga garis mewakili pengulangan ganjil. Variabel posisi yang dimaksudkan adalah penempatan garis-garis pola jahitan yang merujuk pada pengaturan kisi-kisi geometrisdengan pendekatan linear. Variabel eksperimen dapat dilihat pada Gambar 4 dan 5, dengan keterangan sebagai berikut A (Ukuran Jahitan), B (Jarak Jahitan), C (Jarak Antar Jahitan), D (Jumlah Garis), E (Posisi).

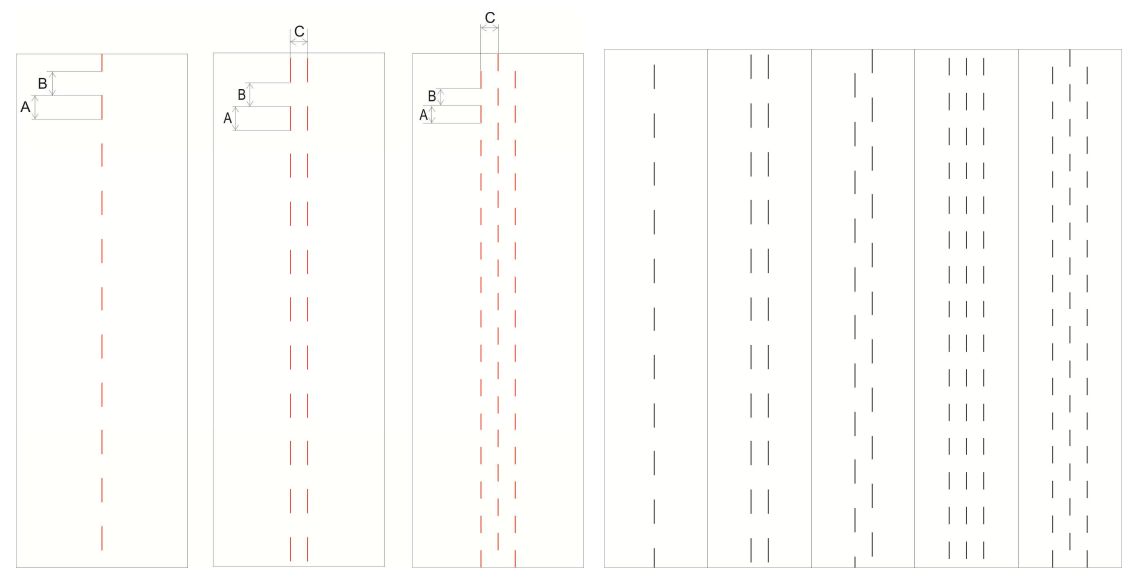

Gambar 4 Variabel pada pola jahitan eksperimen teknik jahit celup.

Gambar 5 Pola lima tahapan eksperimen.

\subsection{Tahap Eksperimen Kedua}

Tahap eksperimen kedua merupakan implementasi dari hasil eksperimen pertama diamana didapat hubungan ukuran, jarak, serta posisi jahitan terhadap motif yang dihasilkan. Dari hasil eksperimen tersebut, dibuat model-model pola 
geometris menggunakan metode grid dengan tujuan untuk melihat potensi pengembangan pola geometris pada teknik tritik. Pembuatan pola menggunakan prinsip-prinsip dasar desain yang telah dijelaskan pada bab kajian teori dimana penentuan ukuran, jarak, serta posisi jahitan akan menimbulkan irama, keseimbangan, pengulangan sehingga menjadi komposisi yang baik [6]. Penggunaan warna pada eksperimen kedua memberikan kesan kedalaman, ruang, ataupun mood. Komposisi warna yang digunakan adalah komposisi monokromatik, analogus, dan komplementer yang terdiri dari dua warna atau lebih. Terdapat sembilan model pola geometris yang digunakan pada eksperimen ini yang diaplikasikan pada material katun, kanvas dan sutra meskipun ada beberapa pola yang tidak diaplikasikan pada salah satu material dengan mempertimbangkan hasil eksperimen sebelumnya (Gambar 6).

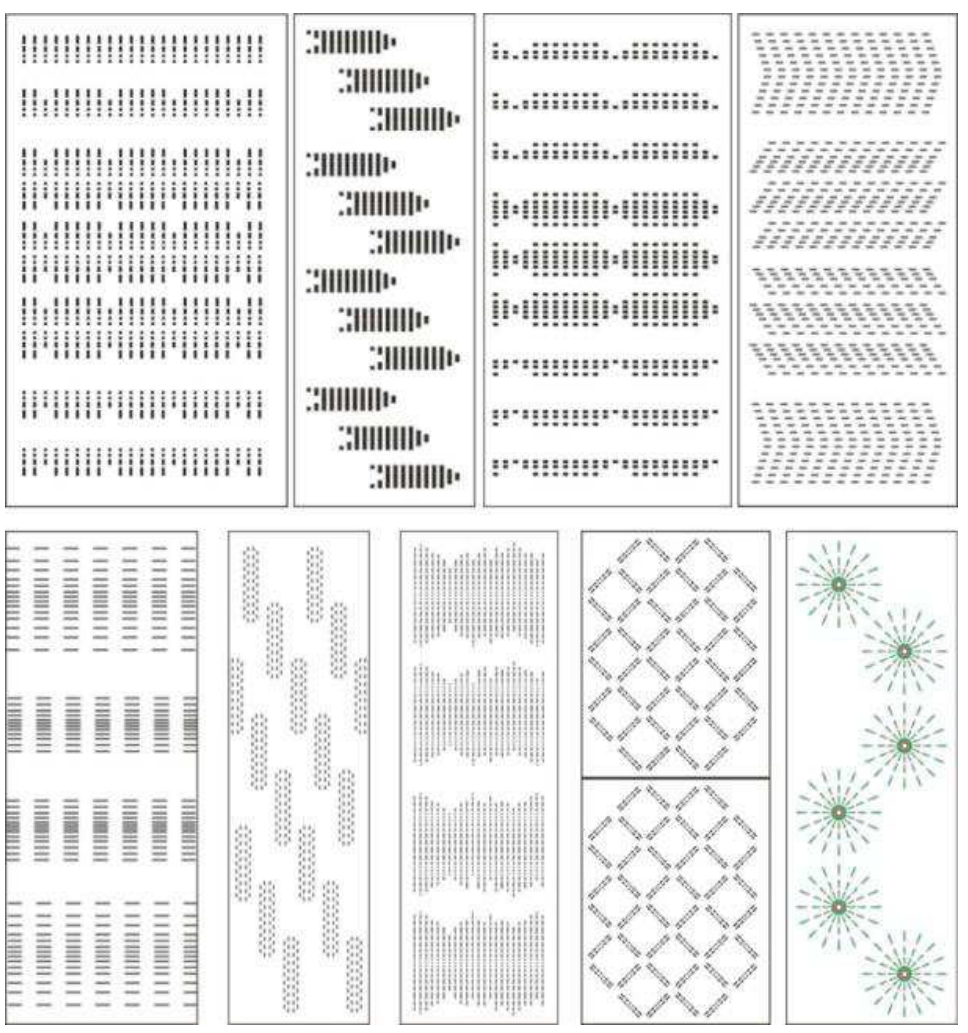

Gambar 6 Pola geometris yang digunakan pada eksperimen tahap kedua. 


\section{Pembahasan Hasil Eksperimen dan Aplikasinya Pada Produk Fashion}

Dari hasil eksperimen yang pertama, didapat hubungan jarak, ukuran, serta posisi jahitan terhadap motif yang dihasilkan pada material tekstil yang berbeda (Tabel 2).

Tabel 2 Hubungan jarak, ukuran, serta posisi jahitan pada teknik tritik.

\begin{tabular}{|c|c|c|c|c|c|c|}
\hline $\begin{array}{l}\text { Jumlah } \\
\text { Baris }\end{array}$ & Posisi & Material & $\begin{array}{c}\text { Ukuran } \\
\text { Garis }\end{array}$ & $\begin{array}{l}\text { Jarak } \\
\text { antar } \\
\text { Garis }\end{array}$ & $\begin{array}{l}\text { Jarak } \\
\text { antar } \\
\text { Baris }\end{array}$ & Karakter Motif \\
\hline \multirow{3}{*}{$\begin{array}{c}1 \\
\text { Baris }\end{array}$} & \multirow{3}{*}{-} & Sutra & $5 \mathrm{~mm}$ & $5 \mathrm{~mm}$ & - & $\begin{array}{l}\text { Deretan titik-titik } \\
\text { berbentuk bulat } \\
\text { sempurna }\end{array}$ \\
\hline & & Katun & $5 \mathrm{~mm}$ & $5 \mathrm{~mm}$ & - & $\begin{array}{l}\text { Deretan titik-titik } \\
\text { berbentuk bulat } \\
\text { yang terpotong }\end{array}$ \\
\hline & & Kanvas & $5 \mathrm{~mm}$ & $5 \mathrm{~mm}$ & - & $\begin{array}{l}\text { Deretan elips yang } \\
\text { terpotong }\end{array}$ \\
\hline \multirow{6}{*}{$\begin{array}{c}2 \\
\text { Baris }\end{array}$} & \multirow{3}{*}{ Sejajar } & Sutra & Max $5 \mathrm{~mm}$ & Max $5 \mathrm{~mm}$ & $5 \mathrm{~mm}$ & \multirow{3}{*}{$\begin{array}{l}\text { Deretan persegi } \\
\text { panjang secara } \\
\text { horizontal yang } \\
\text { tersusun vertikal }\end{array}$} \\
\hline & & Katun & $\begin{array}{c}\operatorname{Max} 10 \\
\operatorname{mm}\end{array}$ & $\begin{array}{c}\operatorname{Max} 10 \\
\mathrm{~mm}\end{array}$ & $\begin{array}{c}5-10 \\
\mathrm{~mm}\end{array}$ & \\
\hline & & Kanvas & $\begin{array}{c}\operatorname{Max} 15 \\
\mathrm{~mm}\end{array}$ & $\begin{array}{c}\operatorname{Max} 15 \\
\operatorname{mm}\end{array}$ & $\begin{array}{l}5-15 \\
\mathrm{~mm}\end{array}$ & \\
\hline & \multirow{3}{*}{$\begin{array}{l}\text { Tidak } \\
\text { sejajar }\end{array}$} & Sutra & Max $5 \mathrm{~mm}$ & Max $5 \mathrm{~mm}$ & $5 \mathrm{~mm}$ & \multirow{3}{*}{$\begin{array}{l}\text { bentuk segitiga } \\
\text { yang berlawanan } \\
\text { dan adanya } \\
\text { kecenderungan pola } \\
\text { perbandingan } \\
\text { ukuran jahitan dan } \\
\text { jarak jahitan = 1:1 }\end{array}$} \\
\hline & & Katun & $\begin{array}{c}\operatorname{Max} 10 \\
\operatorname{mm}\end{array}$ & $\begin{array}{c}\operatorname{Max} 10 \\
\mathrm{~mm}\end{array}$ & $\begin{array}{l}5-20 \\
\mathrm{~mm}\end{array}$ & \\
\hline & & Kanvas & $\begin{array}{c}\operatorname{Max} 20 \\
\mathrm{~mm}\end{array}$ & $\begin{array}{c}\operatorname{Max} 20 \\
\mathrm{~mm}\end{array}$ & $\begin{array}{l}5-20 \\
\mathrm{~mm}\end{array}$ & \\
\hline \multirow{6}{*}{$\begin{array}{c}3 \\
\text { Baris }\end{array}$} & \multirow{3}{*}{ Sejajar } & Sutra & $5-10 \mathrm{~mm}$ & $5-10 \mathrm{~mm}$ & $5-10 \mathrm{~mm}$ & \multirow{3}{*}{$\begin{array}{l}\text { Deretan persegi } \\
\text { panjang secara } \\
\text { horizontal yang } \\
\text { lebih panjang } \\
\text { tersusun vertikal }\end{array}$} \\
\hline & & Katun & $5-15 \mathrm{~mm}$ & $5-15 \mathrm{~mm}$ & $5-15 \mathrm{~mm}$ & \\
\hline & & Kanvas & $5-20 \mathrm{~mm}$ & $5-20 \mathrm{~mm}$ & $5-20 \mathrm{~mm}$ & \\
\hline & \multirow{3}{*}{$\begin{array}{l}\text { Tidak } \\
\text { sejajar }\end{array}$} & Sutra & $5-10 \mathrm{~mm}$ & $5-10 \mathrm{~mm}$ & $5-10 \mathrm{~mm}$ & \multirow{3}{*}{$\begin{array}{l}\text { Segitiga yang } \\
\text { berlawanan dengan } \\
\text { bentuk wajik di } \\
\text { bagian } \\
\text { tengah.Motif } \\
\text { terlihat namun } \\
\text { seringkali tidak } \\
\text { teratur. }\end{array}$} \\
\hline & & Katun & $5-10 \mathrm{~mm}$ & $5-10 \mathrm{~mm}$ & $5-10 \mathrm{~mm}$ & \\
\hline & & Kanvas & $5 \mathrm{~mm}$ & $5 \mathrm{~mm}$ & $5 \mathrm{~mm}$ & \\
\hline
\end{tabular}


Dari Tabel 2, dapat disimpulkan bahwa pada pola yang terdiri dari satu garis, motif yang dihasilkan berupa garis yang terbuat dari titik-titik dengan perbandingan jarak antar jahitan yang semakin besar maka ukuran titik akan semakin mengecil. Pada pola yang terdiri dari 2 garis atau lebih, maka kerutan yang terjadi pada garis satu akan bertemu dengan garis lainnya. Kerutan-kerutan tersebut akan membuat sebuah pola yang mengikuti alur posisi jahitan yang nantinya akan menjadi motif. Semua jenis kain dapat digunakan dengan teknik tritik, walaupun penyerapan warna lebih efektif pada kain yang tipis. Jahitan dengan posisi sejajar akan membentuk motif garis secara horizontal, sedangkan jahitan dengan posisi tidak sejajar akan membentuk motif segitiga dengan ukuran tertentu.

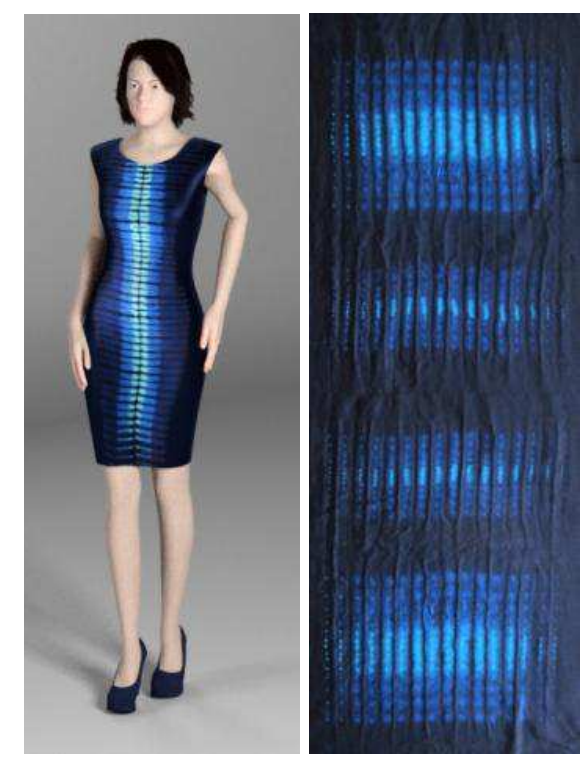

Gambar 7 Aplikasi motif pada perancangan produk fashion yang menonjolkan ilusi optik (body siluet).

Pada tahap eksperimen kedua yaitu penerapan pola geometris pada teknik jahit tritik, dihasilkan hasil yang berbeda dari motif kain sasirangan. Beberapa hal yang didapat dari eksperimen tahap kedua adalah penggunaan pola geometris pada teknik tritik akan dihasilkan motif dengan kesan arah, kedalaman, dan pergerakan (ilusi optik) dengan menggunakan komposisi keseimbangan, irama, dan harmonis yang tepat. Namun, tingkat presisi yang tinggi sangat dibutuhkan saat proses penjahitan untuk menghasilkan komposisi tersebut pada motif kain. Dari ketiga material yang digunakan pada eksperimen, material sutra dirasa mempunyai banyak kelebihan untuk menghasilkan komposisi yang baik karena 
sutra mempunyai tekstur yang mengkilat sehingga menghasilkan pendar yang baik untuk efek gradasi, tingkat kelangsaian yang tinggi juga memberikan hasil terbaik pada kesan arah atau pergerakan. Berdasarkan motif yang dihasilkan dari proses eksperimen, maka konsep perancangan produk fashion adalah menampilkan efek ilusi optik pada produk fashion (Gambar 7 dan 8).
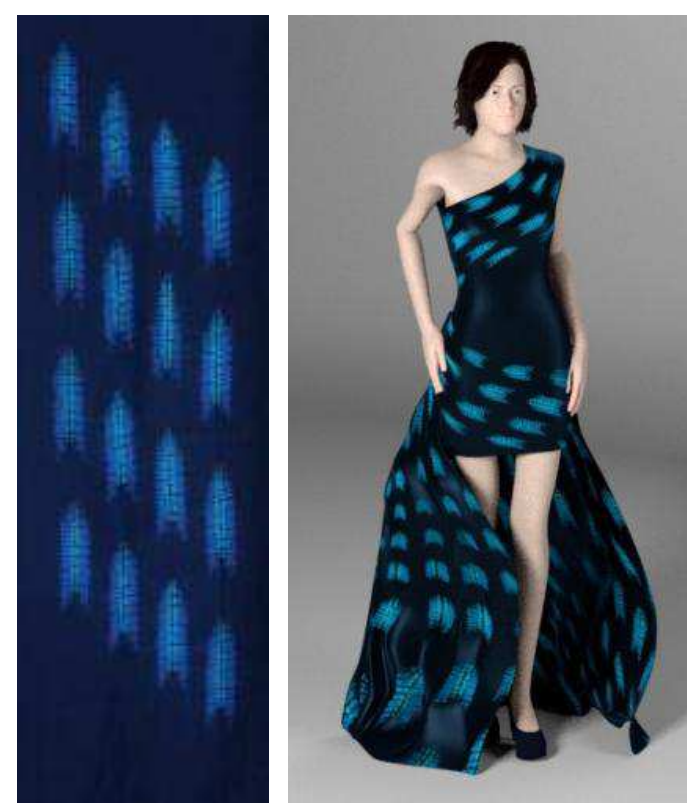

Gambar 8 Aplikasi motif pada perancangan produk fashion yang menonjolkan ilusi optik (movement).

\section{$4 \quad$ Kesimpulan}

Proses pengembangan teknik jahit celup (tritik) dengan pola geometris merupakan suatu implementasi dari usaha membuka peluang-peluang dihasilkannya motif yang berbeda dari motif yang sudah ada selama ini. Dari proses eksperimen dan perancangan, dapat diambil beberapa kesimpulan sebagai berikut:

1. Dalam menghasilkan motif dari teknik tritik, faktor-faktor yang menjadi penentu, adalah cara menjahit, desain pola, material tekstil, dan komposisi warna saat proses pewarnaan.

2. Ukuran, jarak, serta posisi jahitan merupakan faktor penting pada teknik tritik dimana ketiga variabel tersebut akan menghasilkan kerutan yang merupakan media perintang zat warna dalam menghasilkan motif. 
3. Ukuran dan jarak jahitan saling mempengaruhi dalam membuat motif, ukuran dan jarak yang kecil akan menghasilkan motif menyerupai garis (persegi panjang) dan bila menggunakan ukuran yang besar akan berbentuk barisan titik-titik

4. Jumlah garis menjadi suatu variabel tambahan yang menentukan motif, dimana semakin banyak jumlah garis maka area motif yang terjadi akan semakin besar. Posisi yang teratur akan menghasilkan motif yang teratur pula, dan hal tersebut berhubungan juga dengan ketebalan material.

5. Dengan pola geometris, motif yang dihasilkan menampilkan komposisi keseimbangan, irama, dan harmonis serta dengan pengaturan yang tepat dapat memberikan kesan arah, kedalaman, dan pergerakan (ilusi optik).

6. Dari ketiga material yang digunakan pada eksperimen, material sutra mempunyai banyak kelebihan untuk menghasilkan komposisi yang baik karena sutra mempunyai tekstur yang mengkilat sehingga menghasilkan pendar yang baik untuk efek gradasi, tingkat kelangsaian yang tinggi juga memungkinkan dalam menghasilkan efek arah atau pergerakan.

7. Teknik jahit celup merupakan jenis teknik pembuatan motif secara tidak langsung, dimana penerapan pola geometris yang teratur tetap menghasilkan motif yang ekspresif dengan adanya kesan samar yang didapat dari proses pewarnaan yang tidak sempurna di area kerutan (perintang).

8. Motif-motif yang dihasilkan menggunakan pola geometris berbeda dengan motif kain sasirangan yang telah dibuat selama ini, dimana motif kain sasirangan menggunakan teknik jahit celup sebagai garis pinggir (contour). Dengan penggunaan pola geometris menghasilkan motif berupa bidang yang terbentuk dari kumpulan baris-baris yang teratur. Komposisi yang beragam dari pola geometris juga memberikan kesan lebih dinamis berbeda dengan komposisi kain sasirangan saat ini yang sebagian besar disusun secara vertikal.

Dari hasil analisa di atas, dapat disimpulkan bahwa penggunaan pola geometris dapat menghasilkan motif-motif baru dan juga efek ilusi optik dengan komposisi dan pewarnaan yang tepat. Dengan penggunaan pola geometris masih terbuka kemungkinan besar untuk dapat dikembangkan menjadi motif yang lebih beragam bila dikombinasikan dengan tahapan pencelupan yang lebih dari satu kali (gradasi) pada bagian-bagian pola tertentu. Dengan adanya efek ilusi optik yang memberikan kesan kedalaman, arah dan gerak, maka dapat dimanfaatkan untuk membuat dimensi dan ilusi pada produk fashion.

Eksperimen teknik jahit celup dengan pola geometris merupakan tahap awal untuk melakukan pengembangan teknik jahit celup secara menyeluruh. Disarankan untuk diadakan penelitian lainnya untuk mendapatkan hasil yang lebih sinergis, diantaranya: 
1. Penelitian mengenai penggunaan pola, cara pewarnaan, dan material yang berbeda untuk mendapatkan motif yang lebih beragam dari teknik jahit celup, karena teknik ini masih memiliki potensi untuk dikembangkan lebih lanjut.

2. Penelitian teknik tritik dari segi efektivitas produksi dengan mengkonversi teknik tradisional menjadi industrial dengan penggunaan teknologi atau mesin untuk memaksimalkan hasil teknik tritik. Data yang didapat dari pengembangan teknik jahit celup dengan pola geometris menggunakan vector graphics editor dapat dijadikan data awal untuk pengembangan mesin atau program CAM (Computer Aided Manufacture). Hal ini akan menghasilkan pengembangan menyeluruh pada teknik jahit celup agar selaras dengan perkembangan digital textiles saat ini.

\section{Referensi}

[1] Seman, S. 2007. Sasirangan Kain Khas Banjar, Banjarmasin, Lembaga Pengkajian dan Pelestarian Budaya Banjar Kalimantan Selatan. Cetakan I.

[2] Djumena, N.S. 1990. Batik dan Mitra, Penerbit Djambatan, Jakarta.

[3] Kartiwa, Suwati. 1976. Kain Adat (Traditional Textiles), Penerbit Djambatan, Jakarta.

[4] Baldinger, A.S. 1994. Textiles A Classification of Techniques, Smithsonian Institution Press, United State of America.

[5] Belfer, N. 1972. Designing in Batik and Tie Dye, Davis Publications, Inc, Worcester- Massachusetts-USA.

[6] Wallschlaeger, C. \& Busic-Snyder, C. 1992. Basic Visual Concepts and Principles: for Artists, Architects, and Designers, Wm. C. Brown Publishers, USA.

[7] Lorenz, C. 1986. The Design Dimension: Product Strategy and the Challenge of Global Marketing, Basil Blackwell Ltd, UK, 1986.

[8] Bowles, M. \& Isaac, C. 2009. Digital Textile Design, Laurence King Publishing LTD, London.

[9] Segal, W.C., \& Editors of American Fabrics Magazine. 1971. Encyclopedia of Textiles, Prentice-Hall, Inc., New York.

[10] Brown, Pauline. 2002. The Encyclopedia of Embroidery Techniques, Page One Publishing, Singapore. 